\title{
The influence of imports, foreign exchange reserves, external debt, and interest rates on the currency exchange rates against the United States Dollar in Southeast Asia Countries
}

\author{
Rahma Nurjanah; Candra Mustika* \\ Economics Department, Faculty of Economics and Business, Universitas Jambi, \\ Indonesia
}

To whom correspondence should be addressed.Email: candra.mustika@yahoo.com.

\begin{tabular}{|l|l|l|l|l|}
\hline DOI: & Received: & Revised: & Accepted: & Published: \\
$10.22437 /$ ppd.v9i4.12706 & 26.04 .2021 & 15.09 .2021 & 22.10 .2021 & 31.10 .2021 \\
\hline
\end{tabular}

\begin{abstract}
This study aims to analyze the effect of imports, foreign exchange reserves, foreign debt, and interest rates on the currency exchange rates against the United States Dollar in Southeast Asia countries. The study results found that from 2010 to 2017, the currency exchange rates against the United States Dollar in Southeast Asian countries tended to weaken (depreciate). The highest growth in the exchange rate against the United States dollar was in Indonesia, while the lowest was in Singapore. Foreign exchange reserves negatively affect foreign debt, and imports positively affect countries' exchange rates in the Southeast Asia region against the United States dollar. On the other hand, interest rates do not show a significant effect.
\end{abstract}

Keywords: Currency exchange rate, Foreign exchange reserves, Foreign debt, Imports, Interest rates

JEL Classification: F41, F43, F62

\section{INTRODUCTION}

Currency exchange rates are related to government policies, especially monetary authorities. Dornbusch et al. (2018) show that unexpected monetary policy shocks can occur disproportionately and produce large fluctuations in currency exchange rates (overshooting effect). The economic crisis in 1998 had a significant impact on the economies of Asian countries, including the Southeast Asian region. The decline in the value of the currencies of Southeast Asian countries against the United States dollar had a significant impact on changes in macroeconomic variables such as swelling foreign debt, rising prices of imported goods so that economic growth also decreased.

Fluctuations in currency exchange rates for countries in Southeast Asia are highly dependent on factors that influence them, both internal and external. In a free market, changes in Currency exchange rates depend on several factors that affect the supply and demand for foreign exchange. The demand for foreign exchange is related to imports and foreign debt payment. In contrast, the supply of foreign currency depends on the availability of foreign exchange reserves.

Foreign exchange is required to make payment transactions abroad (imports). The higher the income growth rate (relative to other countries), the greater the country's 
ability to import, the greater the demand for foreign exchange. Foreign Currency exchange rates tend to increase, and currency prices will experience a decline. Likewise, an increase in inflation will increase imports and reduce exports. It is will further increase the demand for foreign exchange (Nopirin, 1997).

Currently, countries in Southeast Asia do not have a single currency like countries in Europe. Each country has a different currency. Therefore, changes in the currency exchange rates of countries in the Southeast Asia region will impact both in the short and long term the country's macroeconomic indicators and the countries in the region.

Various studies on the impact of macroeconomic variables on currency exchange rates have been carried out in various countries. Benazic \& Kersan-Skabic (2016) in Croatia found a stable co-integration relationship between the observed variables (ratio between total loans, FDI inflows, consumer prices, and external debt), whereby an increase in the majority of variables leads to an exchange rate appreciation.

Kilicarslan (2018), in Turkey, found that an increase in domestic investment, money supply, and trade openness increases the real effectiveness of exchange rate volatility, while an increase in foreign direct investment, output, and government spending also reduces the real effective exchange rate volatility. On research in Nigeria, Hassan et al. (2017) revealed that net foreign assets and interest rates positively and statistically significantly impact exchange rate volatility while fiscal balance, economic openness, and oil prices have a positive and statistically insignificant impact on exchange rate volatility. Adusei \& Gyapong (2017) in Ghana concluded that inflation, annual GDP growth rate, and total external debt are significant predictors of Currency exchange rates.

In Malaysia, Khin et al. (2017) showed a significant and positive short-term relationship between the exchange rate and the consumer price index. In addition, there is also a significant and negative short-term relationship between the exchange rate and the money supply. Mpofu (2016), in his study in South Africa, found that output volatility, commodity prices, money supply, and foreign exchange reserves significantly affect the exchange rate. Alagidede \& Ibrahim (2017) in Ghana show that the output is the most important driver of exchange rate fluctuations in the short run. In the longer term, exchange rate volatility is significantly affected by government spending and growth in the money supply and terms of trade shocks, FDI flows, and domestic output movements in Ghana.

Cevik et al. (2016) show a high level of exchange rate volatility, especially in emerging market economies. It was also found that the variable "soft power" has a statistically significant effect on exchange rate volatility between countries in 115 countries. Oaikhenan \& Aigheyisi (2015) in Nigeria show that government spending, interest rate movements affect the exchange rate. Insah \& Chiaraah (2013) in Ghana revealed a positive relationship between government spending and exchange rate volatility, while the money supply, domestic and foreign debt are negatively related to exchange rate volatility. Ajao \& Igbokoyi (2013) show that real Currency exchange rates, trade openness, government spending, and real interest rates positively impact exchange rate volatility in Nigeria.

Based on this, this study also aims to examine the impact of macroeconomic variables on currency exchange rates by expanding the study area not only to one country but to six countries in the Southeast Asia region, namely Indonesia, Malaysia, Thailand, Vietnam, the Philippines, and Singapore. The selection of the six countries, considering data availability for the study variables. Furthermore, the macro variables studied include the variables of Imports, Foreign Exchange Reserves, Foreign Debt, and Interest Rates. 


\section{METHODS}

The data used in this study is data from 2010 - 2017 in six countries in the Southeast Asian region. The data is sourced from the Asian Development Bank (ADB). The analytical tool used is the multiple regression model of panel data, with the following model:

$\mathrm{CER}_{\mathrm{it}}=\beta_{0}+\beta_{1} \mathrm{IM}_{\mathrm{it}}+\beta_{2} \mathrm{ED}_{\mathrm{it}}+\beta_{3} \mathrm{FER}_{\mathrm{it}}+\beta_{4} \mathrm{SIR}_{\mathrm{it}}+\varepsilon$

Where:

CER: Currency exchange rates of countries in Southeast Asia against the United States dollar

IM : Import

ED : External Debt

FER: Foreign exchange reserves

SIR : Savings interest rate

i : Cross-section (Indonesia, Malaysia, Singapura, Thailand, Vietnam, Filipina)

t : 2010 to 2017

$\varepsilon \quad:$ Error term

There are three methods of estimation approach that are commonly used: Common Effect Model (CEM), Fixed Effect Model (FEM), Random Effect Model (REM). The Chow test selects the best model between the fixed effect model and the Ordinary Least Square. Hausman's test selects the best model between the random and fixed-effects models. If the results of the two previous tests are obtained in one test or even both tests, accept Ho, a Lagrange Multiplier (LM) test is carried out, also known as the Breusch-Pagan Random Effect. This test selected the best analysis technique between the common and random effect models (Baltagi, 2005).

\section{RESULTS AND DISCUSSIONS}

Developments in currency exchange rates, foreign exchange reserves, imports, interest rates, and foreign debt

\section{The current exchange rate}

The currency exchange rate is one of the most important prices in an open economy because it is determined by the balance between supply and demand that occurs in the market. The current exchange rate growth of countries in Southeast Asia region is given in Figure 1.

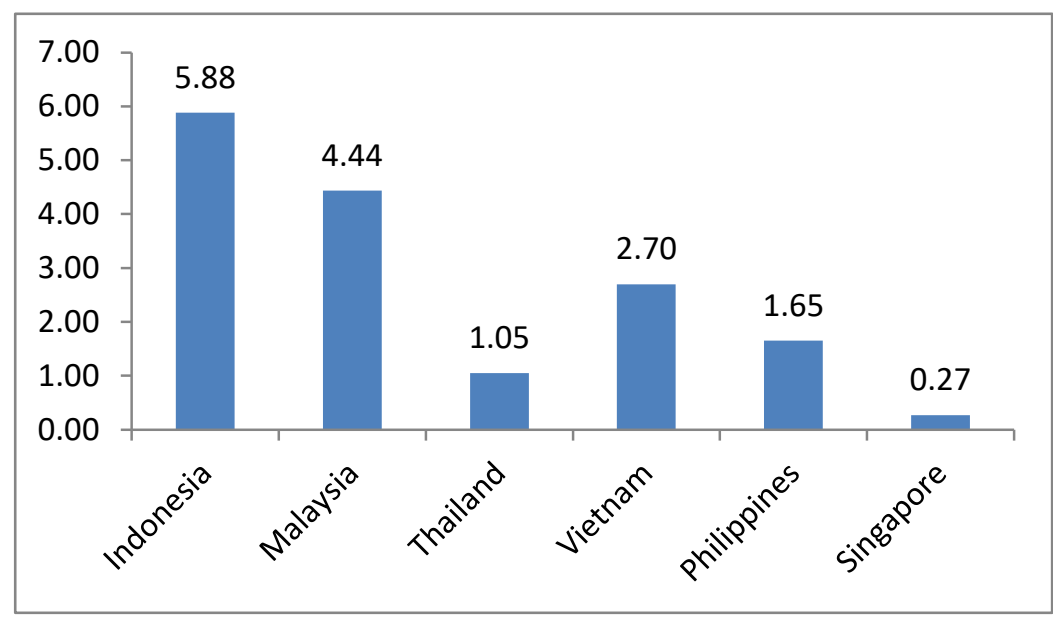

Source: Asian Development Bank (processed data)

Figure 1. The currency exchange rate of countries in Southeast Asia, 2010 - 2017 
During the 2010 - 2017 period, the currency exchange rates of Southeast Asian countries against the United States Dollar tended to weaken (depreciate). The highest depreciation occurred for the Indonesian currency, which was shown by the highest growth of the country's currency exchange rate against the United States dollar (5.88 percent per year). On the other hand, the lowest depreciation is for the Singapore currency. The Singapore dollar tends to be relatively stable, with the exchange rate growth against the United States dollar only 0.27 percent per year.

In Indonesia, the rupiah weakening began at the end of the Suharto presidency and peaked due to the economic crisis that hit Indonesia in 1997-1998. From 2010 to 2017, the main cause of the weakening of the exchange rate was increased foreign debt, increased imports, and the budget deficit.

\section{The foreign exchange reserves}

The foreign exchange reserves are reserves in foreign currency units maintained by the central bank to meet financial obligations due to international transactions (reserve currency). The development of foreign exchange reserves of countries in the Southeast Asia region is given in Figure 2.

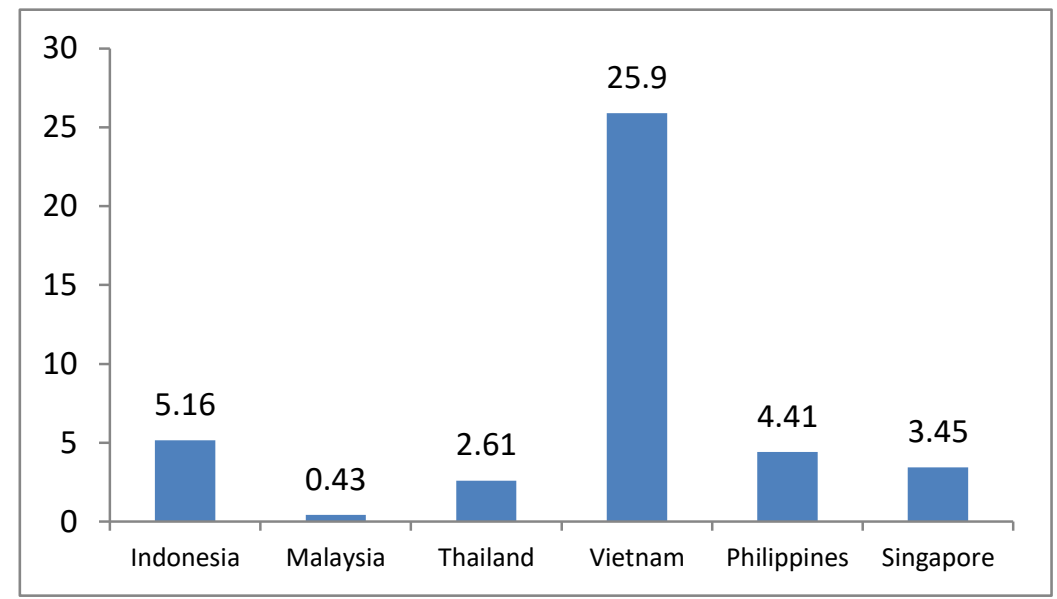

Source: Asian Development Bank (processed data)

Figure 2. The foreign exchange reserves of countries in Southeast Asia, 2010 - 2017

Among the countries in the Southeast Asia Region, Vietnam has the highest growth in terms of foreign exchange reserves. During 2010 - 2017, Vietnam's foreign exchange reserves grew by 25.90 percent. On the other hand, Malaysia has the lowest growth in terms of foreign exchange reserves.

The rapid increase in Vietnam's foreign exchange reserves is due to the country's ability to transform from one of the poorest countries to one of the most successful countries in managing development. The country's success began in the late 1980s. Vietnam can move the economy to meet the domestic market and be oriented to the global market.

\section{External debt}

Most developing countries in the Southeast Asia region require substantial funds to realize national development. The government must manage sources of development financing from available alternatives, both domestically and internationally. If the domestic savings stock is insufficient, one way to obtain capital injections is to attract Foreign Direct Investment (FDI) and External Debt.

The foreign debt of countries in Southeast Asia is given in Figure 3. 


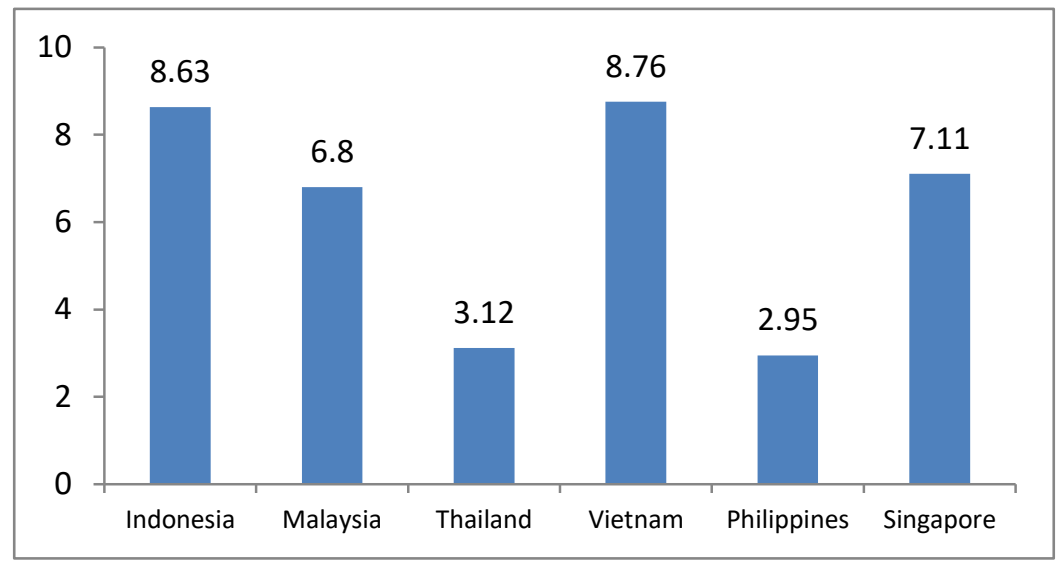

Source: Asian Development Bank (processed data)

Figure 3. External debt of countries in Southeast Asia, 2010 - 2017

Vietnam is also a country with the highest foreign debt growth among countries in the Southeast Asian Region. The average growth of Vietnam's foreign debt reached 8.76 percent per year. On the other hand, the Philippines has the lowest foreign debt growth, only 2.95 percent per year.

Foreign debt has an impact like two different sides of a coin. Without foreign debt, developing countries will not grow their countries faster. On the other hand, inappropriate foreign debt management will cause developing countries to face payment difficulties and uncontrollable burdens. In the case of Vietnam, despite experiencing rapid debt growth, the risk of Vietnam having difficulty repaying its foreign debt is estimated to be relatively small because, at the same time, the country's foreign exchange reserves are also growing rapidly.

\section{Interest Rate}

Interest rate policy is one of the monetary policies to regulate the money supply and maintain the stability of the exchange rate. Changes in interest rates will affect investment in foreign securities. Investors who interact globally will look for countries with favorable interest rates. The rise and fall of foreign investment will affect the country's currency exchange rate.

The average interest rates of countries in the Southeast Asia Region during 2010 2017 are given in Figure 4.

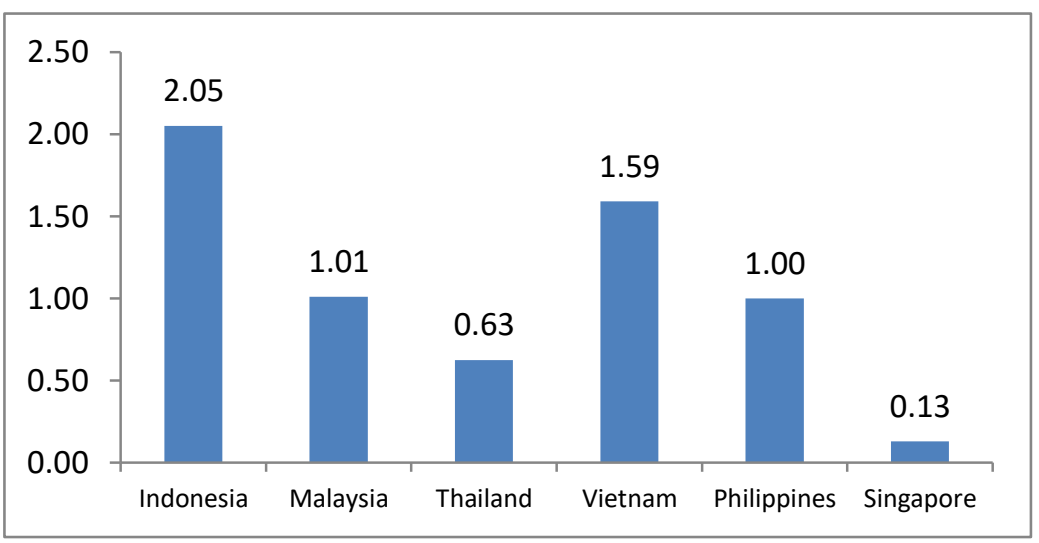

Source: Asian Development Bank (processed data)

Figure 4. Interest rates of countries in Southeast Asia, 2010 - 2017 
Singapore has the lowest average interest rate in the Southeast Asia region, with 0.13 percent. On the other hand, Indonesia has the highest average interest rate of 2.05 percent. The low-interest rate in Singapore will certainly increase the interest of investors to invest in this country. On the other hand, high-interest rates in Indonesia will reduce investors' interest in investing in Indonesia.

\section{Import}

Import activities have the main objective of meeting domestic needs. Import activities will increase the potential of a country in obtaining raw materials, goods, and services for a certain type of product that is limited in number or cannot be produced domestically. It will be able to support the stability of the country indirectly.

Import activities have various benefits, including obtaining goods or services that cannot be produced domestically, obtaining supplies of raw materials, obtaining more advanced technology, controlling inflation, and the state can focus more on producing certain goods or services. However, despite having various benefits, imports also have a negative impact. Imports will cause a loss of competitiveness between domestic and imported products, both in price and quality. Uncontrolled imports will also reduce the country's foreign exchange reserves, which will likely plunge into a deficit.

Import growth of countries in Southeast Asia is given in Figure 5.

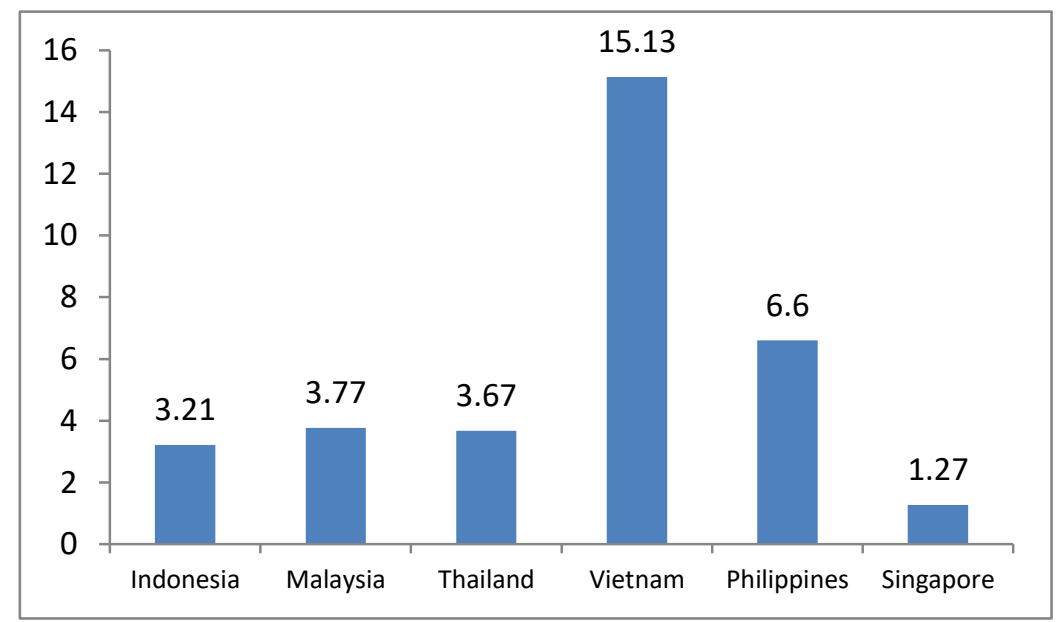

Source: Asian Development Bank (processed data)

Figure 5. Import countries in Southeast Asia, 2010 - 2017

Vietnam has the highest import growth among countries in the Southeast Asian region, with a growth rate of 15.13 percent per year. The high growth of Vietnam's imports implies the rapid increase in consumption in Vietnam, the increase in uppermiddle-class families, and the increasing number of the younger generation. On the other hand, Singapore has the lowest import growth, only 1.27 percent per year.

\section{Determinants of currency exchange rates for countries in the Southeast Asia Region}

Based on the Chow test, Hausman test, and LM test, the common effect model is the best model for analyzing currency exchange rates in countries in the Southeast Asian region. The currency exchange rate model is given in Table 7. 
Table 1. Models of exchange rates for countries in the Southeast Asia Region

\begin{tabular}{rrrrr}
\hline Variable & Coefficient & Std. Error & t-Statistics & \multicolumn{1}{c}{ Prob. } \\
\hline C & 2700,096 & 2950,804 & 0.915037 & 0.3653 \\
CER? & -0.165320 & 0.023602 & -7.004504 & 0.0000 \\
ED? & 0.022003 & 0.011561 & 1.903231 & 0.0637 \\
IM? & 0.091642 & 0.017847 & 5,134996 & 0.0000 \\
SIR? & 1742,394 & 1261,462 & 1.381250 & 0.1743 \\
R-squared & 0.664747 & Mean dependent var & & 5382.200 \\
Adjusted R-squared & 0.633560 & SD dependent var & & 8227,544 \\
SE of regression & 4980,483 & Akaike info criterion & & 19,96277 \\
Sum squared resid & $1.07 \mathrm{E}+09$ & Schwarz criterion & & 20.15769 \\
Log-likelihood & $-474,1066$ & Hannan-Quinn criter. & & 20,03643 \\
F-statistics & 21,31530 & Durbin-Watson stat & & 0.172125 \\
Prob (F-statistic) & 0.000000 & &
\end{tabular}

The model shows that foreign exchange reserves have a significant negative effect on the exchange rate of ASEAN countries' currencies against the United States dollar. An increase in foreign exchange reserves will appreciate the currency exchange rate, and conversely, a decrease in foreign exchange reserves will depreciate the currency exchange rate. This finding is in line with the research by Mpofu (2016), which found that foreign exchange reserves have a significant effect on the exchange rate

Foreign debt and imports have a significant positive effect on currency exchange rates. The positive effect of imports and foreign debt shows that these two variables must be controlled to prevent currency exchange rate depreciation. The significant effect of foreign debt on currency exchange rates is in line with the research findings of Benazic \& Kersan-Skabic (2016) in Coatia, Adusei, and Gyapong (2017) in Ghana and Mpofu (2016) in South Africa. The significant effect of imports on currency exchange rates is in line with research by Benazic \& Kersan-Skabic (2016) in Croatia, and several studies in Ghana (Adusei \& Gyapong, 2017; Alagidede \& Ibrahim, 2017; Ajao and Igbokoyi (2013)

The model shows that of the four variables that affect the currency exchange rates of ASEAN countries, only interest rates do not have a significant effect. The findings of this study are different from the findings of previous studies, which showed a significant effect of interest rates on currency exchange rates (Ajao \& Igbokoyi, 2013; Hassan et al., 2017; Oaikhenan \& Aigheyisi, 2015)

\section{CONCLUSIONS AND RECOMMENDATIONS}

\section{Conclusions}

The highest depreciation occurred for the Indonesian currency, which was shown by the highest growth of the country's currency exchange rate against the United States dollar (5.88 percent per year). On the other hand, the lowest depreciation is for the Singapore currency. The Singapore dollar tends to be relatively stable, with the exchange rate growth against the United States dollar only 0.27 percent per year.

Of the four variables studied, only interest rates do not affect countries' exchange rates in the Southeast Asia region. Foreign exchange reserves have a negative effect, while foreign debt and imports positively affect currency exchange rates.

\section{Recommendations}

To control the currency exchange rate, the government and the private sector are advised to control the rate of imports and foreign debt. If complete data is available for further research, this research should be extended to all countries in the Southeast Asian region. Further research is also suggested to add other macroeconomic variables which theoretically are suspected to affect currency exchange rates. 


\section{REFERENCES}

Adusei, M., \& Gyapong, E. Y. (2017). The impact of macroeconomic variables on exchange rate volatility in Ghana: The Partial Least Squares Structural Equation Modelling approach. Research in International Business and Finance, 42, 14281444.

Ajao, M. G., \& Igbekoyi, O. E. (2013). The determinants of real exchange rate volatility in Nigeria. Academic Journal of Interdisciplinary Studies, 2(1), 459-471.

Alagidede, P., \& Ibrahim, M. (2017). On the causes and effects of exchange rate volatility on economic growth: Evidence from Ghana.Journal of African Business, 18(2), 169-193.

Asian Development Bank (2018). Economic Indicators For Eastern Asia: Input-Output Tables. Accessed from www.adb.org.

BPS. (2010). Indikator Sosial Ekonomi Indonesia. Jakarta: BPS Statistic Indonesia.

Baltagi, B. H. (2005). Econometric Analysis of Panel Data (3ed.). Chicester, England: John Wiley \& Sons Ltd.

Benazic, M., \& Kersan-Skabic, I. (2016). The determinants of exchange rate in Croatia. Eastern journal of european studies, 7(1), 125.

Boediono. (2004). Ekonomi internasional. Bagian Penerbitan Fakultas Ekonomi, UGM.

Cevik, S., Harris, R. D., \& Yilmaz, F. (2017). Soft power and exchange rate volatility. International Finance, 20(3), 271-288.

Dornbusch, R., Fischer, S., \& Startz, R. (2018). Macroeconomics $13^{\text {th }}$ Edition. McGraw-Hill. Inc., New York.

Dumairy. (1996). Perekonomian Indonesia. Jakarta: Erlangga.

Gaspersz, V. (1997). Manajemen kualitas: penerapan konsep-konsep kualiutas dalam manajemen bisnis total. Jakarta: Gramedia.

Gujarati, D. N. (2009). Basic econometrics. Tata McGraw-Hill Education.

Greene, W. H. (2000). Econometric analysis 4th edition. International edition, New Jersey: Prentice Hall.

Halwani, R. H. (2018). Ekonomi Internasional \& Globalisasi Ekonomi. Jakarta: Ghalia Indonesia.

Hady, H. (2001). Ekonomi Internasional: teori dan kebijakan perdagangan internasional. Buku Kesatu. Jakarta: Ghalia Indonesia.

Hassan, A., Abubakar, M. I., \& Dantama, Y. U. (2017). Determinants of Exchange Rate Volatility: New Estimates from Nigeria. Eastern Journal of Economics and Finance, 3(1), 1-12.

Herlambang, T., Sugiarto, B., \& Said, K. (2001). Ekonomi Makro: Teori Analisis dan Kebijakan. Jakarta: Gramedia Pustaka Utama.

Insah, B., \& Chiaraah, A. (2013). Sources of real exchange rate volatility in the Ghanaian economy. Journal of Economics and International Finance, 5(6), 232.

Khin, A. A., Yee, C. Y., Seng, L. S., Wan, C. M., \& Xian, G. Q. (2017). Exchange Rate Volatility on Macroeconomic Determinants In Malaysia: Vector Error Correction Method (Vecm) Model. Journal of Global Business and Social Entrepreneurship (GBSE), 3, 36-45.

Kilicarslan, Z. (2018). Determinants of exchange rate volatility: empirical evidence for Turkey. Journal of Economics Finance and Accounting, 5(2), 204-213.

Lindert, P. H. (1994). Ekonomi Internasional. Jakarta: Bumi Aksara.

Mankiw, N. G. (2003). Teori Makro Ekonomi Terjemahan. Jakarta: Erlangga.

Mpofu, T. R. (2016). The determinants of exchange rate volatility in South Africa. Economic Research Southern Africa, Working Paper, 604.

Kuncoro, M. (2003). Metode riset untuk bisnis dan ekonomi. Jakarta: Erlangga, 52.

Nopirin, P. D. (2000). Ekonomi Internasional. Yogyakarta: BPFE-Yogyakarta. 
Oaikhenan, H. E., \& Aigheyisi, O. S. (2015). Factors explaining exchange rate volatility in Nigeria: theory and empirical evidence. Economic and Financial Review, 53(2), 47-77

Tan, S. (2004). Ekonomi Internasional. Jakarta: Citra Prathana.

\section{APPENDIX}

Table 2. Currency exchange rates, foreign exchange reserves, imports, interest rates, and external debt in Indonesia, 2010 - 2017

\begin{tabular}{|c|c|c|c|c|c|c|c|c|c|}
\hline Year & $\begin{array}{l}\text { Exc. } \\
\text { Rate } \\
\text { (Rp) }\end{array}$ & $\begin{array}{c}\text { Growth } \\
(\%)\end{array}$ & $\begin{array}{l}\text { Forg. Exc. } \\
\text { Rsv. (Million } \\
\text { US \$) }\end{array}$ & $\begin{array}{c}\text { Growth } \\
(\%)\end{array}$ & $\begin{array}{l}\text { Debt } \\
\text { (Million } \\
\text { US \$) }\end{array}$ & $\begin{array}{c}\text { Growth } \\
(\%)\end{array}$ & $\begin{array}{c}\text { Interest } \\
(\%)\end{array}$ & $\begin{array}{c}\text { Import } \\
\text { (Million } \\
\text { US \$) }\end{array}$ & $\begin{array}{c}\text { Growth } \\
(\%)\end{array}$ \\
\hline 2010 & 9090 & & 89970 & & 198269 & & 3.9 & 135663 & \\
\hline 2011 & 8770 & -3.52 & 103611 & 15.16 & 219620 & 10.76 & 2.3 & 177436 & 30.79 \\
\hline 2012 & 9387 & 7.03 & 105907 & 2.21 & 252556 & 14.99 & 1.8 & 191691 & 8.03 \\
\hline 2013 & 10461 & 11.44 & 93427 & -11.78 & 265453 & 5.10 & 1.9 & 186629 & -2.64 \\
\hline 2014 & 11865 & 13.42 & 106073 & 13.53 & 292971 & 10.36 & 1.8 & 178179 & -4.52 \\
\hline 2015 & 13389 & 12.84 & 100626 & -5.13 & 308221 & 5.20 & 1.7 & 142695 & -19.91 \\
\hline 2016 & 13308 & -0.60 & 110931 & 10.24 & 316431 & 2.66 & 1.5 & 135653 & -4.93 \\
\hline 2017 & 13381 & 0.54 & 124143 & 11.91 & 352250 & 11.31 & 1.5 & 156925 & 15.68 \\
\hline Average & & 5.88 & & 5.16 & & 8.63 & 2.05 & & 3.21 \\
\hline
\end{tabular}

Source: Asian Development Bank

Table 3. Currency exchange rates, foreign exchange reserves, imports, interest rates, and external debt in Malaysia, 2010 - 2017

\begin{tabular}{cccccccccc}
\hline Year & $\begin{array}{c}\text { Exc. } \\
\text { Rate } \\
\text { Rp) }\end{array}$ & $\begin{array}{c}\text { Growth } \\
(\%)\end{array}$ & $\begin{array}{c}\text { Forg. Exc. (Million } \\
\text { US \$) }\end{array}$ & $\begin{array}{c}\text { Growth } \\
(\%)\end{array}$ & $\begin{array}{c}\text { Debt } \\
\text { (Million } \\
\text { US \$) }\end{array}$ & $\begin{array}{c}\text { Growth } \\
(\%)\end{array}$ & $\begin{array}{c}\text { Interest } \\
(\%)\end{array}$ & $\begin{array}{c}\text { Import } \\
\text { (Million } \\
\text { US \$) }\end{array}$ & $\begin{array}{c}\text { Growth } \\
(\%)\end{array}$ \\
\hline 2010 & 3.22 & - & 102325 & - & 133800 & - & 0.94 & 164730 & - \\
2011 & 3.06 & -4.96 & 128964 & 26.03 & 144898 & 8.29 & 1.08 & 187645 & 13.91 \\
2012 & 3.09 & 0.98 & 134940 & 4.63 & 193880 & 33.80 & 1.04 & 196588 & 4.76 \\
2013 & 3.15 & 1.94 & 130492 & -3.29 & 188795 & -2.62 & 1.01 & 206125 & 4.85 \\
2014 & 3.27 & 3.80 & 111765 & -14.35 & 196587 & 4.12 & 1.03 & 208920 & 1.35 \\
2015 & 3.91 & 19.57 & 91429 & -18.19 & 190951 & -2.86 & 1.06 & 176051 & -15.73 \\
2016 & 4.15 & 6.13 & 91194 & -0.25 & 200364 & 4.92 & 1 & 178101 & 1.16 \\
2017 & 4.3 & 3.61 & 98938 & 8.49 & 204371 & 1.99 & 0.96 & 206745 & 16.08 \\
\hline Average & - & 4.44 & - & 0.43 & - & 6.80 & 1.01 & - & 3.77 \\
\hline
\end{tabular}

Source: Asian Development Bank

Table 4. currency exchange rates, foreign exchange reserves, imports, interest rates, and external debt in Thailand, 2010 - 2017

\begin{tabular}{cccccccccc}
\hline Year & $\begin{array}{c}\text { Exc. } \\
\text { Rate } \\
\text { (Rp) }\end{array}$ & $\begin{array}{c}\text { Growth } \\
(\%)\end{array}$ & $\begin{array}{c}\text { Forg. Exv. (Million } \\
\text { US \$) }\end{array}$ & $\begin{array}{c}\text { Growth } \\
(\%)\end{array}$ & $\begin{array}{c}\text { Debt } \\
(\text { Million } \\
\text { US \$) }\end{array}$ & $\begin{array}{c}\text { Growt } \\
\text { h }(\%)\end{array}$ & $\begin{array}{c}\text { Interest } \\
(\%)\end{array}$ & $\begin{array}{c}\text { Import } \\
(\text { Million } \\
\text { US \$) }\end{array}$ & $\begin{array}{c}\text { Growth } \\
(\%)\end{array}$ \\
\hline 2010 & 31.69 & - & 165656 & - & 106358 & - & 0.5 & 185121 & - \\
2011 & 30.49 & -3.78 & 165200 & -0.27 & 109943 & 3.37 & 0.9 & 229137 & 23.77 \\
2012 & 31.08 & 1.93 & 171106 & 3.57 & 134257 & 22.11 & 0.7 & 250453 & 9.30 \\
2013 & 30.73 & -1.12 & 159022 & -7.06 & 137353 & 2.30 & 0.6 & 249577 & -0.34 \\
2014 & 32.48 & 5.69 & 149064 & -6.26 & 135292 & -1.50 & 0.8 & 227895 & -8.68 \\
2015 & 34.25 & 5.44 & 149291 & 0.15 & 129654 & -4.16 & 0.5 & 201790 & -11.45 \\
2016 & 35.3 & 3.06 & 164148 & 9.95 & 121497 & -6.29 & 0.5 & 195103 & -3.31 \\
2017 & 33.94 & -3.85 & 194048 & 18.21 & 128814 & 6.02 & 0.5 & 227194 & 16.44 \\
\hline Average & - & 1.05 & - & 2.61 & - & 3.12 & 0.625 & - & 3.67 \\
\hline
\end{tabular}

Source: Asian Development Bank 
Table 5. Currency exchange rates, foreign exchange reserves, imports, interest rates, and external debt in Vietnam, 2010 - 2017

\begin{tabular}{cccccccccc}
\hline Year & $\begin{array}{c}\text { Exc. } \\
\text { Rate } \\
(\mathrm{Rp})\end{array}$ & $\begin{array}{c}\text { Growth } \\
(\%)\end{array}$ & $\begin{array}{c}\text { Forg. Exc. } \\
\text { Rsv. (Million } \\
\text { US \$) }\end{array}$ & $\begin{array}{c}\text { Growth } \\
(\%)\end{array}$ & $\begin{array}{c}\text { Debt } \\
(\text { Million } \\
\text { US \$) }\end{array}$ & $\begin{array}{c}\text { Growth } \\
(\%)\end{array}$ & $\begin{array}{c}\text { Interest } \\
(\%)\end{array}$ & $\begin{array}{c}\text { Import } \\
(\text { Million } \\
\text { US \$) }\end{array}$ & $\begin{array}{c}\text { Growth } \\
(\%)\end{array}$ \\
\hline 2010 & 18613 & - & 12054 & - & 44902 & - & 3 & 83378 & - \\
2011 & 20510 & 10.19 & 13128 & 8.90 & 53886 & 8.00 & 3 & 104438 & 25.25 \\
2012 & 20828 & 1.55 & 25161 & 91.65 & 61577 & 14.27 & 2.2 & 111680 & 6.93 \\
2013 & 20933 & 0.50 & 25481 & 1.27 & 65452 & 6.29 & 1.3 & 129294 & 15.77 \\
2014 & 21148 & 1.02 & 33801 & 32.65 & 72430 & 10.66 & 0.8 & 144824 & 12.01 \\
2015 & 21698 & 2.60 & 27879 & -17.52 & 77827 & 7.45 & 0.7 & 175784 & 21.37 \\
2016 & 21935 & 1.09 & 36167 & 29.72 & 86952 & 11.72 & 0.93 & 185292 & 5.40 \\
2017 & 22370 & 1.98 & 48693 & 34.63 & 79069 & -9.06 & 0.81 & 220869 & 19.20 \\
\hline Average & - & 2.70 & - & 25.90 & - & 8.76 & 1.59 & - & 15.13 \\
\hline
\end{tabular}

Source: Asian Development Bank

Table 6. Currency exchange rates, foreign exchange reserves, imports, interest rates, and external debt in the Philippines, 2010 - 2017

\begin{tabular}{|c|c|c|c|c|c|c|c|c|c|}
\hline Year & $\begin{array}{l}\text { Exc. } \\
\text { Rate } \\
\text { (Rp) }\end{array}$ & $\begin{array}{c}\text { Growth } \\
(\%)\end{array}$ & $\begin{array}{l}\text { Forg. Exc. } \\
\text { Rsv. } \\
\text { (Million US } \\
\$ \text { ) }\end{array}$ & $\begin{array}{c}\text { Growth } \\
(\%)\end{array}$ & $\begin{array}{l}\text { Debt } \\
\text { (Million } \\
\text { US \$) }\end{array}$ & $\begin{array}{c}\text { Growth } \\
(\%)\end{array}$ & $\begin{array}{c}\text { Interest } \\
(\%)\end{array}$ & $\begin{array}{l}\text { Import } \\
\text { (Million } \\
\text { US \$) }\end{array}$ & $\begin{array}{c}\text { Growth } \\
(\%)\end{array}$ \\
\hline 2010 & 45.11 & & 53991 & & 65358 & & 1.6 & 60193 & \\
\hline 2011 & 43.31 & -3.99 & 65700 & 21.68 & 66114 & 1.15 & 1.6 & 66159 & 9.91 \\
\hline 2012 & 42.23 & -2.49 & 71656 & 9.06 & 69372 & 4.92 & 1.3 & 67886 & 2.61 \\
\hline 2013 & 42.45 & 0.52 & 73792 & 2.98 & 66202 & -4.56 & 0.8 & 68014 & 0.18 \\
\hline 2014 & 44.4 & 4.59 & 70260 & -4.78 & 78559 & 18.66 & 0.6 & 70976 & 4.35 \\
\hline 2015 & 45.5 & 2.47 & 72352 & 2.97 & 80623 & 2.62 & 0.7 & 73355 & 3.35 \\
\hline 2016 & 47.49 & 4.37 & 71853 & -0.68 & 77319 & -4.09 & 0.7 & 91427 & 24.63 \\
\hline 2017 & 50.4 & 6.12 & 71598 & -0.35 & 78833 & 1.95 & 0.7 & 92839 & 1.54 \\
\hline Average & & 1.65 & & 4.41 & & 2.95 & 1 & & 6.6 \\
\hline
\end{tabular}

Source: Asian Development Bank

Table 7. Currency exchange rates, foreign exchange reserves, imports, interest rates, and external debt in Singapore, 2010 - 2017

\begin{tabular}{|c|c|c|c|c|c|c|c|c|c|}
\hline Year & $\begin{array}{l}\text { Exc. Rate } \\
\text { (Rp) }\end{array}$ & $\begin{array}{c}\text { Growth } \\
(\%)\end{array}$ & $\begin{array}{l}\text { Forg. Exc. } \\
\text { Rsv. } \\
\text { (Million US } \\
\$ \text { ) }\end{array}$ & $\begin{array}{l}\text { Growth } \\
(\%)\end{array}$ & $\begin{array}{l}\text { Debt } \\
\text { (Million } \\
\text { US \$) }\end{array}$ & $\begin{array}{c}\text { Growth } \\
(\%)\end{array}$ & $\begin{array}{c}\text { Interest } \\
(\%)\end{array}$ & $\begin{array}{l}\text { Import } \\
\text { (Million } \\
\text { US \$) }\end{array}$ & $\begin{array}{c}\text { Growth } \\
(\%)\end{array}$ \\
\hline 2010 & 1,364 & & 223678 & & 228263.9 & & 0.14 & 310879 & \\
\hline 2011 & 1,271 & -6.75 & 260656 & 16.53 & 305192.9 & 33.70 & 0.11 & 361618 & 16.32 \\
\hline 2012 & 1,297 & 2.02 & 256922 & -1.43 & 306556 & 0.44 & 0.13 & 345472 & -4.46 \\
\hline 2013 & 1,251 & -3.59 & 270484 & 5.27 & 307582.4 & 0.33 & 0.1 & 373081 & 7.99 \\
\hline 2014 & 1,267 & 1.27 & 254562 & -5.88 & 301440.3 & -1.99 & 0.11 & 366301 & -1.81 \\
\hline 2015 & 1,375 & 8.52 & 245721 & -3.47 & 310645.3 & 3.05 & 0.14 & 297035 & -18.90 \\
\hline 2016 & 1,382 & 0.50 & 244366 & -0.55 & 343549.2 & 10.59 & 0.14 & 282022 & -5.05 \\
\hline 2017 & 1,381 & -0.07 & 277813 & 13.68 & 356180.7 & 3.67 & 0.16 & 324024 & 14.89 \\
\hline Average & & 0.27 & & 3.45 & & 7.11 & 0.13 & & 1.27 \\
\hline
\end{tabular}

Source: Asian Development Bank

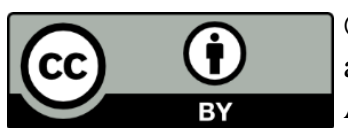

